\title{
An Overview of the Development of Management Accounting Research
}

\author{
SITI NABIHA ABDUL KHALID \\ School of Management \\ Universiti Sains Malaysia
}

\begin{abstract}
There has been significant changes in the direction of management accounting research since the 1980 's and 1990's, from the prescriptive and normative research of the late 1950's and 1960's to the positivistic research in the 1970's and 1980's. As such, the purpose of this article is to provide an overview of this development. First, the paper discusses the characteristics of traditional management accounting research. Then, a reflection is given on the debate, which started in the 1980's regarding the limitations of traditional management accounting research. It could be said that the 1980's was a decade of re-evaluation for management accounting, both in terms of the research undertaken and in terms of techniques and practices. Now, various theoretical frameworks are used by researchers and new and innovative techniques are being implemented in organisations. The scope of management accounting has also been broadened from those based on economics perspective to a broader based approach.
\end{abstract}

\begin{abstract}
ABSTRAK
Terdapat perubahan yang ketara dalam arah tuju penyelidikan perakaunan pengurusan pada tahuntahun 1980-an dan 1990-an, daripada penyelidikan preskriptif dan normatif pada akhir dekad 1950-an dan 1960-an kepada penyelidikan positivis dalam tahun 1970-an dan 1980-an. Tujuan artikel ini adalah untuk memberikan gambaran tentang perkembangan ini. Pertama, artikel ini membincangkan ciri-ciri penyelidikan pengurusan perakaunan yang tradisional. Kemudian, artikel ini membincangkan mengenai perdebatan, yang bermula sekitar tahun 80-an, mengenai limitasi penyelidikan perakaunan pengurusan. Boleh dikatakan bahawa tahun 1980-an merupakan dekad penilaian semula di dalam bidang perakaunan pengurusan, baik dari segi cara penyelidikan dibuat mahupun dari segi praktis dan teknik-tekniknya. Pada masa ini, pelbagai model theoretik yang digunakan oleh para penyelidik dan teknik-teknik yang baru dan inovatifyang diimplementasikan oleh berbagai-bagai organisasi. Skop pengurusan perakaunan juga telah diperluaskan daripada pendekatan yang berasaskan perspektif ekonomi kepada perspektif yang lebih luas lagi.
\end{abstract}

\section{INTRODUCTION}

There has been significant changes in the direction of management accounting research over the last forty or fifty years. Such changes have been influenced by a number of interrelated factors. Over this period, various research methods, from surveys to case studies, have been employed. A variety of theoretical approaches, from contingency theory to institutional theory, have been utilised by researchers.

The purpose of this paper is to provide an overview $^{\mathrm{i}}$ of the development in management accounting research. First, it discusses the 
development of traditional management accounting research. Both the economics and behavioural branch of accounting is emphasised. Traditional accounting research as is used here encompasses those research or approaches that have objectivist orientations, within the functionalist paradigm and hence, largely ignore the social and organisational context in which accounting operates. It is important to clarify here that such a broad conceptualisation is not meant to dismiss the distinct characteristics of each research approach. A single simple tag is a dangerous way to characterise a large and diverse body of work. However, there are some similar unifying assumptions of these research and they can be used to cluster these types of research together.

The second part of the paper gives a reflection of the debate, which started in the mid 1980s's regarding the limitations of traditional management accounting research. A number of published articles that questioned the underlying assumptions of traditional management accounting were published during this period. At about the same time, there were calls made, notably by Kaplan in the US and Hopwood in UK, urging researchers to study accounting in its organisational context. The mid 1980's has also generated interest in both management accounting research and its practice. Johnson and Kaplan's book "Relevance Lost: The Rise and Fall of Management Accounting', published in the mid 1980's has generated interest in the study of management accounting.

Besides the influences of theoretical debates published in academic journals, significant changes in environmental conditions have further contributed and influenced the direction of management accounting research. The rapid changes in technology, especially information technology, the changes in business environment and advances made in the discipline have further influenced the direction of research, the way they are undertaken and the specific issues highlighted. A major change during this period of time is the use of the nontraditional approach in undertaking management accounting research which took off during the mid 1980's and subsequently flourished in the 1990's. These approaches are discussed in the third part of this paper. In addition, one of the important research issues in the 1990's, concerning management accounting change is also discussed. This paper concludes with several main points regarding the development of management accounting research.

\section{TRADITIONAL ACCOUNTING RESEARCH (1950'S TO MID 1980'S)}

In the period before the 1950's, management accounting was mainly developed by engineers and practitioners (Scapens, 1990). Academic researchers were actively involved in management accounting research only after the second World War (Scapens, 1990). In the 1950's and 1960's, management accounting research was mainly prescriptive whereby researchers proposed techniques that should be used in practice. Neo-classical economics framework was mainly used. As such, the underlying assumptions of neo-classical economics, i.e., rationality of managers, profit maximizing objective, perfect and costless information were accepted and not questioned. Group decision-making was not taken into consideration because each individual manager is rational and will maximize profits. Since there are no uncertainty and information costs, all members of the organization will arrive at the same decision. Therefore, individual decision-making is indistinguishable from the group's decision.

By the 1960's, management accounting research had expanded rapidly. Management accounting techniques were developed and refined. With the development of the notion of different costs for different purposes, there is a shift from the concept of absolute truth of cost accounting to the conditional truth of management accounting. Profit maximization was achieved by using marginal economic analysis, i.e., comparing the benefits against costs of decisions. Researchers developed mathematical models to analyse management accounting problems. However, these models had little impact on practice.

Developments in the field of information economics in the 1960's, made it possible for researchers to evaluate the costs of information. Restrictive assumptions that were accepted by the 
previous researchers could now be relaxed. Uncertainty was introduced in the decision model, and this lead to the question of costs and the value of information. As such, there was the recognition that there it is a rational action on the part of the practitioners to use simple techniques due to uncertainty and the costs of obtaining information. Practitioners should not be criticized for using simpler techniques and not the more complex techniques that were advocated by management accounting researchers since those models did not take into account the problems of implementation and the cost of obtaining information.

There was a change in emphasis in management accounting research in the 1970's and 1980's, from normative to the positivistic research. Positivistic management accounting researchers also tried to explain and predict management accounting practices. The researchers also tried to develop theory ${ }^{\mathrm{ii}}$ that encompassed practice. Interest in studying management accounting practices developed due to the perceived gap between theory and practice (Scapens, 1990). At first, questionnaires and surveys were used. This, however, gives only a general and superficial view of practice and subsequently led to the call to study accounting in action.

Although it could be said that neoclassical economics provided the dominant influence (Scapens, 1991), management accounting has also been greatly influenced by organisational theories (OT). The use of theoretical approaches in management accounting research has, to some extent, mirrored that of the organisational theorists. This is reflected in the use of scientific management in the early budgeting research to the use of human relations perspective from the 1950's to the 1970's and in the use of contingency theory in the 1970's and well into 1980's. However, (Otley, 1984) maintains that all the major traditions in OT that have influenced management accounting research are within the functionalist paradigm. To illustrate, the traditional theory of budgeting had its origins from the classical organisational theory, namely from the scientific management principles of F.W. Taylor. The view within this approach is that there is one way of behaving which is most effective. There was also the assumption that budgets and standards for human and organisational performance can be set in a more or less objective and scientifically verifiable manner. Accountability, authority and control are the main emphasis of such an approach (Schiff \& Lewin, 1970).

The scientific management approach was criticised because it views organisation as a coercive system, which insists on accountability and control, and imposed budget was the instrument used to achieve control and uniformity (Schiff \& Lewin, 1970). With the advent of human relations thinking this view changed. This theory views that employees' participation can solve many of the organisational problems. Thus, the ideas of employees participating in the budgetary process were soon applied in management accounting literature. It was accepted that employees' participation could lead to a more effective use of budgets (Macintosh, 1985).

Human relations thinking in management accounting started from a study undertaken by the National Industrial Conference Board in 1931 (Macintosh, 1994). The study maintained that imposed budgets might lead to both positive and negative consequences. It was suggested that managers prepared the budgets which can then be revised and reviewed by the organisation's top executives at the later stages. Hence, the initial idea of having participative budgeting emerged. Twenty years later, a study by (Argyris, 1952), explored the effects of budgets. Argyris's study provided interesting insights to a number of budgeting issues and it influenced the direction of budgeting research in subsequent years. Hence, the human relations movement have had a significant impact on management accounting research since it provided the underlying theories for some of the earliest behavioural ${ }^{\mathrm{iii}}$ accounting research (Emmanuel et. al., 1990).

Organisational theories that were used before the 1950's were universalist in approach in that they were trying to find one best organisational solution. Likewise, management accounting research which had used classical organisational theory and human relations insights have a common underlying feature, that is finding one best way to manage, motivate or organise (Emmanuel et al., 1990). As an example, the prescription provided by Argyris to confound the 
negative consequences of budgets was to have supervisors participate in the budgeting process. The suggestion is universal and it implicitly assumes that participation would work for all organisations irrespective of the organisational circumstances and environmental conditions. Hence, it is accepted that there is a one best way of setting up the management accounting system. This forms the basis of the foundations of behavioural accounting research well into the 1970's (Otley, 1984).

In the 1950's and 1960's, nearly all organisational researchers accepted that there is not one best organisational solution. Certain forms of organisations are best suited to particular environmental conditions. By mid-1960's, contingency theory had been developed in the organisational literature. The basic idea of the contingency theory is that there is no one best way to manage or organise. The way an organisation is designed will depend on its environmental circumstances since different organisational structures are appropriate for different circumstances (Emmanuel et al., 1990).

Even though the contingency theory was developed by the mid 1960 's, there was no explicit reference of the theory in management accounting research before the mid 1970's (Otley, 1980). The contingency theory was most actively used by management accounting researchers from the mid 1970's to the 1980's. The contingency theory expounds that there is no one appropriate accounting system that is applicable for all organisations (Otley, 1980). The type of accounting system used would depend on the environment facing the organisation (Preston, 1995). Within such a frame of reference, the roles of researchers and practitioners are to discover the best accounting techniques or procedures that will best match the organisation (Covaleski et al., 1985).

This contingency theory is of considerable importance to management accounting research as it has dominated behavioural accounting research since 1975. Furthermore, as (Otley, 1980) maintains, the popularity of the contingency theory in management accounting research was primarily due to the empirical necessity, i.e., resulting from the conflicting findings from the research undertaken. The development of the con- tingency theory in organisational theory literature provided the researchers with a ready-made theory (Otley, 1980). However, it was accepted without criticism by management accounting researchers at the time when it was being seriously criticised by the organisational theorists.

Both strands of research informed by neoclassical economics and organisational theory have similar underlying assumptions. By the mid 1980 's, there was a serious questioning of these assumptions which were either implicitly or explicitly accepted by researchers. The debate, to some extent, has contributed to the change in direction of management accounting research.

\section{THE 1980'S: REEVALUATION PERIOD}

The 1980's was an exciting era in management accounting research. It could be said that the 1980 's was the decade of re evaluation of management accounting, both in terms of research undertaken and in terms of techniques and practices. There were many interrelated influences and development during this period. First, there were considerable debates starting around the mid1980's regarding the limitations of traditional management accounting paradigm. It was in the 1980 's and well into the 1990's that numerous papers were published which questioned the assumptions of traditional management accounting research (see for example Tinker et al., 1982; Chua 1986, 1988; Hopper \& Powell, 1985; Puxty, 1993; Scapens, 1990, 1994; Baker \& Bettner, 1997). These papers suggested that traditional management accounting research has an objectivist orientation and some unifying characteristics. These assumptions, it has been argued, have limitations and as such cannot not provide great insights into the nature of management accounting.

The first limitation is that within the traditional paradigm, matters concerning management accounting are seen only from the organizational perspective (Puxty, 1993). Furthermore, there is no distinction between the perspectives of the organization from the perspectives of the managers. In addition, traditional management accounting has an implied assumption of an individual 
decision maker who is isolated from other decision makers in the organisation. Group decisionmaking was not considered or was ignored (Scapens, 1991).

This traditional paradigm is also reductionist in approach because the only phenomenon that is considered relevant is the economic phenomena and social effects and actions can be reduced to individual effects and actions (Puxty, 1993). Thus, optimising the function of the individual managers will in effect optimise the functions of the organisation as a whole. The perspective of the managers does not differ from the perspective of the organisation. As such, traditional management accounting paradigm is based on a managerialist perspective. The main focus is on managers, their functions and the functions of the management accounting system in the organisation. In addition, managerialist critiques were prescriptive and descriptive and they could not provide an enhanced understanding about the management system in action (Macintosh, 1985). Most of the research has a technical orientation whereby the organization is evaluated based on the efficiency in which it achieves its objectives (Puxty, 1993).

The traditional paradigm also claims to avoid the political issues in society. Value has no place or was claimed not to be included in the analysis. Accounting is seen as an objective and neutral technique and an independent technical phenomenon. For example, budgeting is seen as a rational process of resource allocation. Accountants are seen as dealing only with the most efficient and effective means of providing the information needs of the managers. As for the researchers, they should not be involved in the moral judgements of the decision makers.

These traditional approaches are problem driven and directed towards improving and refining management accounting to better serve exogenously given organizational goals and thus, they are somewhat narrow in focus (Covaleski et al., 1996). The main objective is to achieve economic efficiency. Accounting phenomena are defined in terms of problems to be solved. Phenomena that are not considered as problems are ignored while phenomena that are considered as problems are approached in such a way as to im- ply that there is something wrong that can be fixed. Accounting existence is necessitated by the supposition that people will not improve their behaviour without the surveillance of an accounting system. People have failings which will cause them to be slack. A well-designed accounting system will help to rectify this by channelling the organisation's energy into activities desirable by the organisation (Puxty, 1993).

The criticism against the traditional management accounting paradigm is that it does not lived up to its claims or underlying assumptions. Even though it is said that value judgements are not within the realm of the research, the fact is that the traditional paradigm is based on the managerialist perspectives is sufficient enough to implicate managerial accounting politically if we acknowledge that all interests in the organization are not in congruence with the managers' interest (Puxty, 1993). The ontological assumption within the traditional accounting paradigm is that there exists an objective reality which is independent of the researcher or of the subjects (Kaplan, 1984; Chua 1986, Hopper \& Powell, 1985). The subject's values, biases or background have no effect on how he or she perceives the reality. Thus, the reality exists independently of the researcher and is governed by empirical laws that can be discovered. These assumptions influence the context and the way research is undertaken (Kaplan, 1984). The emphasis within this paradigm is to search for the regularities and the causal relationship (Kaplan, 1984) and there is a gain in knowledge when researchers discover this relationship or the objective reality (Chua, 1986).

Given such assumptions, it is not surprising that a forma ${ }^{\text {iv }}$ methodology was preferred and used. The research method most commonly used by researchers was questionnaire surveys. The earlier researchers, for example Argyris and Hofstede, mostly used descriptive case studies. However, most of the research, especially in the 1980's, used cross sectional questionnaire surveys with hypotheses testing. The emphasis is on control, that is the manipulation of variables to achieve the desired end states (Chua, 1988). The researcher's objective is to search for regularities and causal relationships (Kaplan, 1984; Chua, 1988). Thus, the researchers are interested in the 
questions of 'why' instead of 'how' (Chua, 1988). For example in finding the causal relationship between the participation in budgets setting and job satisfaction. Accounting choices are seen as having real and objective economic consequences, which are measurable (Kaplan, 1984). The analysis is ahistorical because it does not explain the choices and the behaviours of the people as a result of their past experiences (Puxty, 1993).

Most of the assumptions discussed above are derived from neo-classical economics which has had a great influence in traditional management accounting thinking. As Otley (1984) argues, even though management accounting is about providing information, the underlying theoretical approach has derived from economics where the rational model is dominant. There have been various criticisms and limitations of using such a framework in management accounting (see Shiozawa, 1999; Scapens, 1990). For example, Scapens (1990) argues that neo-classical economics is a theoretical model that is used by the economists to derive hypotheses and consequently obtain predictions about certain economic phenomena. The economists never intended it to be a normative theory of how managers should behave. The framework was used to predict an individual firm's activities in aggregate. Whereas, management accounting concerns with the individual firm and individuals within the firm. As such, Scapens (1990) argues that neo-classical economics might be useful in the management accounting context if it were to be used in predicting some phenomena in aggregate.

Furthermore, neoclassical economics is inadequate in studying social phenomena since it views individuals as being independent of political, social and organisational factors. Such factors are assumed to have a minimal impact on individuals (Spechler, 1990). Individuals live and interact in society, but they are not changed or affected by these social interactions (Bartlett, 1994). As such, the use of power, group considerations, choices and purposes are ignored or excluded from neoclassical analysis. Even the organisational theories that were used have been argued not to provide any great insights. For example, Macintosh (1985) argues that, even though several insights were gained, human relations research on budgeting did not bring into focus the broader social, political and economic settings within which budgeting systems operate.

As a result of the limitations of the traditional management accounting paradigm, arguments were advanced for the use of alternative forms of management accounting research. Following the different ontological assumptions being proposed, there were also changes in the research methods adopted in management accounting studies. Case and field based research methods became increasingly used (Spicer, 1992). In addition, concerns that the complex mathematical decision models such as linear programming, which had been advanced by researchers in the 1970's and the 1980's, had largely been ignored by the practitioners led to an interest in studying management accounting practices (Scapens, 1990, 1999). At first researchers were concerned to change practice, but this later shifted to the need to understand practice (Scapens, 1999).

Third, another debate which also started in the mid 1980's arose from Johnson's and Kaplan's (1987) assertion that management accounting had not changed and had failed to respond to the challenge of the changing business environment. Johnson and Kaplan maintained that the techniques that were in the management accounting textbooks had in fact already been used by the US industrial corporations since 1925. As a result, conventional management accounting techniques were said to be irrelevant and were subjected to various criticisms. Johnson and Kaplan claimed that there was a crisis in management accounting and as such, the need for change. Kaplan notably urged researchers to look for new innovative management accounting techniques in modern day organisations. However, Scapens (1990) argues that this would mean that the researcher is able to identify the best practice and distinguish it from the inferior one. Furthermore, Scapens (1999) argues that the researcher, in identifying the best practice, will be influenced by his or her conception of the nature of management accounting practices. Since then research, from field surveys to case studies have been undertaken to determine whether there have been any changes in management accounting practice. In addition, there have been arguments that the use of non- 
financial measures has led to changes in management accounting. Hence, there have been other debates on whether management accounting has changed or resisted change (Burns \& Scapens, 2000).

\section{THE NEW ACCOUNTING RESEARCH - POST 1980's}

The scene of management accounting research starting from the mid-1980's, especially in the United Kingdom, has changed considerably. There has been a renewed interest, over the last fifteen years, among management accounting researchers to study management accounting practices and subsequently, in the use of field studies (Young, 1999). Prior to the mid 1980's, field studies comprised less than $5 \%$ of published research (Young, 1999). Most of the research during that time employed the use of statistical techniques. As mentioned, there were a number of factors that precipitate the interest, such as the debate during the 1980 's as discussed above, the calls to study accounting in practice and also the rapidly changing business environment.

It is doubtful whether traditional positivistic research still holds mainstream position in the UK. In the United States, despite the calls by some US researchers to study accounting in action, the positivistic approach still holds mainstream position. There is still a lack of research from alternative insights published by mainstream accounting journals, especially those that are US-based (Baker \& Bettner, 1997). The types of research published are mostly from positivistic perspectives with the usual emphasis on quantitative methods. Shield (1997) in his review of research published by US academicians in the 1990's found that most of the researchers employed the use of hypothetico-deductive method.

Various terms have been used to categorise the non-traditional accounting research ${ }^{\mathrm{v}}$. In this article, the term used is new management accounting research (hereafter designated as NAR) which refers to research which is non-positivistic in its orientation and is attentive to the social and organisational character of accounting. Hence, NAR encompasses diverse theoretical perspectives and different empirical foci. Various theoretical frameworks have been utilised such as Giddens structuration theory, the labour process perspective, Habermas, Foucault and the institutional theory, among others. The 'new' accounting academics have opened their field to academics trained in different traditions (sociology, history etc) in the development of NAR (Morgan \& Willmott, 1993).

NAR has several distinct characteristics. First, it questions the idea that accounting is understandable and significant only as a technical activity, rather than as a social and organizational practice. Accounting is not an independent phenomenon. It can be changed by organisational and wider societal factors and can also act as a vehicle for organisational transformation (Hopwood, 1987; 1990; Ezzamel et al., 1999; Libby \& Waterhouse, 1996). Hence, the new streams of accounting research, to varying degrees, move towards considering accounting as a practice instead of just as a technique (Covaleski et al., 1996). It acknowledges accounting as being constituted of and constituted by the social and organisational relations (Morgan \& Willmott, 1993; Covaleski et al., 1996).

Following this, NAR discards the idea that it is possible to study accounting independently of the study of the social and organisational contexts (Broadbent \& Guthrie, 1992). Hence, within the NAR community, there is the acceptance of the importance of the context in which accounting operates, albeit to different degrees. Accounting actively and politically constitutes the world rather than passively and neutrally regulates or reports it. Accounting techniques have the potential to shape behaviour and perceptions. The work does not wholly accept or at the extreme reject that accounting can necessarily be successful as a powerful force for change (Broadbent \& Guthrie, 1992). It seeks to move towards a critical evaluation of the processes which have been implemented (Broadbent \& Guthrie, 1992). Such views are different from traditional management accounting research which usually examines 
management accounting procedures and techniques with the intent of improving its efficiency.

The first alternative paradigm used in management accounting research is the interpretive $^{\text {vi }}$ approach (Roslinder, 1995 \& Baker $\&$ Bettner, 1997). The interpretivists have different ontological assumptions regarding the natural and the social world (Willmott, 1983). Social phenomenon is viewed as different from natural phenomenon since the nature of social phenomena depends on how they are related to other actions or phenomena (Whitley, 1988). If the other phenomena change, there also will be change in the particular actions or roles. Reality is socially constructed, emergent and is continuously being redefined. The idea of a single objective reality was rejected because each organisational member interprets the situation in his or her own way but they are preconditioned by the organisational and social factors. Therefore, interpretive studies do not claim generalisability or universality in their conclusion. Surveys, experimental designs and other methodologies that are based on having an objective reality are inappropriate since they are inconsistent with the theoretical underpinnings of this paradigm (Hopper \& Powell, 1985). Qualitative methodology is preferred since it provides an intensive study of the world of the subjects and it also emphases their meanings, views and perceptions.

Using this approach indicates a major shift in thinking about management accounting. Management accounting is seen as being constituted and given meanings by social actions. Management accounting also plays a role in shaping organisational reality and in determining what is important and unimportant (Chua, 1988). It is seen as a socially constituted phenomenon with the full implications of power and politics. Once the practices are implemented, what it accounts for will shape the organisational views of what constitutes reality (Covaleski et al., 1996). Thus, accounting does not engage in an objective and value free enterprise. They themselves are constructors of organisational reality. As opposed to the traditional perspective, the interpretivist sees accounting information as not being value-free. Accounting information has diverse meanings and they are actually an inadequate representation of reality (Chua, 1986). Research undertaken within this perspective requires a detailed study of accounting practices in its original setting.

The second alternative approach that is used by the new accounting researchers are the radical $^{\text {vii }}$ theories (Puxty, 1993). These radical perspectives in accounting research are marked by different theoretical approaches and methodologies used and the wide range of issues and topics addressed (Covaleski et al., 1996). Covaleski et al. (1996) classify these variant approaches as critical theories due to their main attention to the interrelation between accounting and issues of conflict, domination and power. The approaches within the critical theories avoid the consensus view of society. Two perspectives that provide a significant impact on management accounting are the labour process and the Foucaultian perspectives.

Labour process perspectives focus on the way the group that hold power or privileged position will hold the other in check through using controls over power resources. Management accounting is one of the tools used for this purpose. As for the accounting researchers who use this approach, their objective is to uncover the role of management accounting and control systems whereby a small number of executives rules and exploit the rest of the employees. These are more readily seen in a period of crisis than in periods of stability when contradictions can be veiled.

Society, within the labour process approach, is viewed as being capitalistic. The focus is on the relation of production between the owner and labour and what this relationship means for the parties involved. The nature of the political and social system is one of permanent hierarchy. Society is characterized by different classes, conflicting interests between the groups and of dominant exploitation of one group over another. Thus, structural inequalities are inherent in the system. These inequalities will be reflected in the organizations whereby some groups will dominate and exploit the others. The view of organization moves from co-operation and having mutual purposes to that of employers exploiting the workers and ex- 
propriating their surplus values. From this perspective, the nature of society is different reflecting a society that is different and thus, a different nature and role of management accounting (Puxty, 1993). In order to understand the labour process approach, the features and characteristics that make up a society need to be known because they will influence or determine organizations in that system and subsequently, these will be reflected in the nature of management accounting. Therefore, within this perspective the focus will not only be on the organization and the individual participants alone because they are linked to the whole social and individual systems.

Another critical approach is the Foucaultian approach, which draws from the works of Michael Foucault and has a significant influence on management accounting thinking and research. Foucaultian insights and modes of analysis have been used in management accounting research. Accounting is seen as being wholly implicated in the structures of surveillance and power. For example, instead of viewing the advent of standard costing and budgeting as due to progress made by the businesses, the managers and the owner (Kaplan, 1984) or as a way of protecting shareholders' returns from economic uncertainty (Hopper \& Armstrong, 1991), Miller \& O’Leary (1987), using the Foucaultian approach argue that budgeting is used to provide visibility and accountability for every employee in the company. The advent of standard costing has made visible the activities of workers at the factory; and likewise, the emergence of budgeting has made it possible for activities of managers to be made visible and accountable.

Now NAR is fairly well established. There are now journals such as Accounting, Organization and Society; Critical Perspectives in Accounting, and Management Accounting Research, which have provided the avenues for the publication of new accounting research.

The next section discusses one of the important research issues in the 1990 's, that is regarding management accounting change. This issue is of considerable interest to management accounting researchers due to the rapidly changing environment facing businesses and also due to Johnson and Kaplan's (1987) lost relevance thesis.

\section{MANAGEMENT ACCOUNTING CHANGE: THE 1990'S}

Johnson and Kaplan's (1987) assertion that management accounting had not changed and had failed to respond to the challenge of the changing business environment has also sparked another debate. Since the publication of their work, research, from field surveys to case studies have been undertaken to determine whether there have been any changes in management accounting practices. Interest in studying management accounting change was also fuelled by the changes in both the internal and external environment of the organisation. The changes which faced businesses in the 1970's and 1980's accelerated during the 1990 's. The tremendous changes, especially in information and manufacturing technology, have resulted in strains on the management of profit and also non-profit organisations (Spicer, 1992).

Contemporary organisations now consist of multifunctional teams, the use of non-financial measures together with financial performance measures, the reorganisation of organisations into business units and the decentralisation of accounting (Innes \& Mitchell, 1990b). Additionally, advances in production technology have led to the development of machine and equipment performance. The changes in technology have affected management accounting since they have made it possible for new accounting measures to be produced. There are changes in the way performance is measured at the individual and organisational level. Furthermore, the decentralisation of accounting has led to an increase in communication between accountants and other managers and has facilitated accounting change (Innes \& Mitchell, 1990b; Ezzamel et al., 1997).

There is also evidence that the roles of accountants and also of other managers have also changed due to changes in the wider environment and the existence of multifunctional teams (Chenhall \& Langfield-Smith, 1998; Burns \& Baldvinsdottir, 1999). Some of the works of accountants are undertaken by non-accountants, giving rise to such terms as hybrid or pseudo-accountants (Scapens, 1999). Arguments have been advanced for the reform of accounting practices so that they can serve the needs of modern organisa- 
tions (Ezzamel et al., 1999). In line with this, various new techniques have been proposed as a panacea for the ineffectiveness of traditional management accounting techniques in responding to the rapidly changing business environment. Among these 'new' techniques were activity-based accounting, activity-based management, Japanese management accounting techniques (i.e., target costing, and Kaizen costing), balance scorecards, and strategic management accounting. In addition, new management techniques, such as total quality management, value based management and benchmarking have also been proposed, usually with the claim that they will improve the performance of organisations and make them more proactive in the changing environment.

Unlike the 1970's and early 1980's, when new management accounting techniques were advocated by researchers, many of the more recent new techniques for improvements have been proposed by consultants and practitioners (Bromwich, 1998). Various companies are implementing these new management accounting techniques, in part due to the advice of consulting firms or due to the publicity given to these techniques in the business press and seminars.

Due to the above factors, there has been resurgence in the study of management accounting change. From the 1990's onwards, research has been carried out to examine management accounting change in practice. This research can be divided into three broad categories. First, there is the research that focuses on the technical aspects of the implementation of new techniques, such as ABC or ABB (for example Innes \& Mitchell, 1990a; Gietzmann, 1991; Anderson, 1995). This research concentrates on the technical issues of management accounting change. However, this type of research has been argued to be unable to provide an enhanced understanding of the phenomena of management accounting change (see Hopwood, 1983, 1987; Miller, 1994; Covaleski et al., 1996). One of the criticisms is that the functionalist view of accounting change provides only a limited understanding of the process and the consequences of accounting change.

Hopwood (1987) states that little is known about the processes of accounting change, that is the forces that either influence accounting change or help to shape the different forms of accounting and the consequences of such changes. Hopwood's argument is still valid today. More than a decade after he wrote, his view is echoed by other researchers. For example, Libby and Waterhouse (1996) note that there is not much knowledge about the forces that induce or act to impede change in accounting practice. Furthermore, not much is known about the micro processes of change, that is processes of change at the firm specific level (Innes \& Mitchell, 1990b; Burns 2000). There is then an acknowledgement of the importance of studying accounting change and its processes.

The second and third categories of research examine accounting change within the wider social and organisational context. However, there are some differences between these two categories. The second category of research in management accounting change focuses on the external factors (i.e., the environment, the regulatory bodies, the government or the market leader) and how they impact on the organisation. Research with this approach has a more macro focus. Some of the studies in this category are those of Covaleski et al., 1993; Jacobs, 1995; \& Collier, 1999.

In the third category, the emphasis is on studying processes of change within the organisation. Research in this category focuses on the internal working processes of the organisation; that is, the forces that promote or hinder such changes. However, there is very little research in this category, especially in relation to why and how these new techniques become or fail to become an embedded way of doing things in the organisation. Research in this category includes the work of Burns and Scapens, 1996; Vaivio, 1999; \& Burns, 2000.

Despite numerous researches that explore management accounting change, not much is known about the micro processes of change, that is processes of change at the firm specific level (Innes \& Mitchell, 1990b; Burns 2000). There are still important questions that need answers. For example, how do members of the organisation cope with the process of change? Why is there such a demand for the new management techniques? What are the conditions and situations which give rise to the new methods? 


\section{CLOSING DISCUSSION}

So what have we learned from nearly sixty years of management accounting research? This paper concludes with four main points. First, one of the important implications is that the view of management accounting has broadened over the years. There is now the recognition of the wider role of accounting. Previously, management accounting was seen as a neutral tool and device that could be used to achieve organisational goals. Now, there is the recognition that management accounting is a social and institutional practice which is essential in the creation of reality. As Miller (1994) succinctly states "The technical practice of accounting is intrinsically and irredeemably social" (p. 4).

Management accounting is not an autonomous phenomenon, but is part of organisational practice. It can be changed by organisational and wider societal factors, and it can also act as a vehicle for organisational transformation (Hopwood, 1987, 1990; Libby \& Waterhouse, 1996; Ezzamel et al., 1997). As Hopwood argues the power of accounting lies in its ability to provide an objectification of economic facts and visibility to organisational activities. It is this potential that gives accounting the ability to transform the organisation. Furthermore, there is the recognition that management accounting should be known for what it does in specific context rather than what it might be able to do in a generalised and abstract arena. The introduction of contextual elements in management accounting research means that the horizon of accounting research has widened considerably (Copper \& Hopper, 1990).

Second, the way management accounting is conceptualised has also changed. Initially management accounting was defined based on the economic perspective (Scapens, 1999). For example Kaplan (1984, p. 414) defines management accounting as "The process of identification, measurement, accumulation, analysis, preparation, interpretation and communication of financial information used by management to plan, evaluate and control within an organization". This definition is relatively similar to those given in most textbooks which see management accounting as encompassing the techniques which can be used to provide information for managers to assist in their decision-making. A more recent widely used management accounting textbook defines management accounting as being "concerned with the provision of information to people within the organization to help them make better decisions" (Drury, 1996, p. 4). Drury, however, proceeds to provide the attributes of economics information. There are arguments that such a view of management accounting is too restrictive, since it is based primarily on economic perspectives. Scapens (1999, p. 640) proposes a broader conceptualisation of management accounting. He defines it as "...management accounting is concerned with integrating financial and other aspects of the business, and the interconnections between operations, financial performance and strategy". Such a definition locates management accounting in a broad organisational context and does not focus solely on the economic or financial information used for decision-making (Scapens, 1999). The wider roles of accounting, i.e., both the economic and the non-economic aspects, are now being taken into consideration.

Third, there has been proliferation of new management accounting techniques over the last decade. We still remember what happened to zero based budgeting in the 1970's. Would the new techniques face the same fate as zero-based budgeting? For example, one of the new techniques advocated is Activity Based Costing and it was met with huge enthusiasm as a better and more relevant approach to costing in the mid 1980's and in the early 1990's. However, as researchers and organisations have gained experience of $\mathrm{ABC}$, there have been criticisms of the technique. There are evidences of difficulties and failures faced by organisations in implementing ABC. Furthermore, there is the argument that the adoption of new management accounting techniques might be due to institutional pressures.

Fourth, as we have seen, various theoretical and methodological approaches have been utilised by management accounting researchers. As mentioned, the new management accounting research is fairly well established. However, there is still the need for comparing, contrasting and 
synthesizing results across cases (Hopper, 1999). As such, management accounting still remains an interesting area for research.

\section{ENDNOTES}

i This paper does not claim to provide an extensive nor intensive review of management accounting research. What is provided is only a flavour of the development of this research over the years.

ii Watts and Zimmerman, two of the most influential positivistic accounting researchers, maintain that the objective of an accounting theory is to explain and predict accounting practices. The theory provides reasons for observed accounting practices and predict the unobserved accounting phenomena (Watts and Zimmerman, 1986, p.2)

iii Otley (1984) explains that the term "behavioural accounting" is actually a misnomer since all accounting is concerned with affecting human behaviour. However, he maintains that the term is used "... to identify work in accounting that has specifically attempted to incorporate individual, group and organizational variables" (Otley, 1984, p. 150).

iv Wilber and Harison (1978) explain that "Formalism is a method that consist of a formal system of logical relationship abstracted from any empirical content it might have the real world. For example, the theory of the firm in standard economics deals with the behavior of the firm involved in any process of production, using any inputs and at any set of relative prices with any technology. It is characterized by use of mathematics (at least implicitly) and by the development of axiomatic deductive structure." (p. 62, emphasis in original)

For example, Roslinder (1995) uses the term critical theory to encompass all approaches other than those within the traditional accounting paradigm or the functionalist paradigm. He uses this type of classification because the new approaches, such as the interpretivist, the Foucauldian and the labour process perspectives, provide a non-technical and a critical view of management accounting. As for Young (1999), he uses the term 'New' Accounting Research to encompass research that is attentive to the social character of accounting theory and practice. Broadbent and Guthrie (1992) in their review of research into public sector accounting use the term 'alternative accounting research'.

vi There were a number of different terms used by researchers in the accounting literature to describe this approach. For example the terms used are the naturalistic approach (Willmott, 1983; Tomkins and Groves, 1983), interpretive approach (Chua, 1986, 1988; Covaleski et al., 1996), interactionist or interpretive sociology (Roslinder, 1995). Now the term 'interpretive' is commonly used to describe this approach.

vii Again, there are a number of terms used to describe this approach. Puxty used the term 'radical theory'. However, Covaleski used the term 'critical theory'.

\section{REFERENCES}

Anderson, S. (1995). A framework for assessing cost management system changes: the case of activity based costing improvement at General Motors 1986-1993. Journal of Management Accounting Research, 8 147-167.

Argyris, C. (1952). The impact of budgets on people. The Controllership Foundation. New York : Ithaca

Baker, C., \& Bettner, M. (1997). Interpretive and critical research in accounting: a commentary on its absence from mainstream accounting research. Critical Perspectives on Accounting, 8 293-310. 
Bartlett, R. (1994). Power (I) in G. Hodgson, W. Samuel and M. Tool (eds.) The Elgar Companion to Institutional and Evolutionary Economics, L-Z. Aldershot: Edward Elgar, 169173.

Broadbent, J. \& Guthrie, J. (1992). Change in organisations: a case study of the use of accounting information in NHS. British Accounting Review, 24, 343-367.

Bromwich, M. (1998). Editorial: value based financial management system. Management Accounting Research, 9, 387-389.

Burns, J. (2000). The dynamics of accounting change: Inter-play between new practices, routines, institutions, power and politics. $A c$ counting, Auditing and Accountability Journal, 13 (5), 566-96.

Burns, J. \& Baldvinsdottir, G. (1999). Hybrids: the changing roles of accountants in Stam plc. paper presented at the Conference on Management Accounting Change: A European Perspective. Manchester, 14-17 April.

Burns, J. \& Scapens, R. (1996). The institutionalization of accounting routines: Ferac International. Annual Collection of Wards Trust Seminar Papers, Glasgow University, (1).

Burns, J. \& Scapens, R. (2000). Conceptualising management accounting change: an institutionalist framework. Management Accounting Research, 11 (1), 3-25.

Chenhall, R. \& Langfield-Smith, K. (1998). Factors influencing the role of management accounting in the development of performance measures within organizational change programs. Management Accounting Research, 9, 361-386.

Chua, W. F. (1986). Radical development in accounting thought. The Accounting Review, LXI : (4), 601-632.
Chua, W.F. (1988). Interpretive sociology and management accounting research: A critical review. Accounting, Auditing and Accountability Journal, 1 (2), 59-79.

Clegg, S. \& Hardy, C. (1996). Conclusions: Representations in Clegg, S., C. Hardy and W. Nord (eds.) Handbook of Organizational Studies, London: Sage, 59-79.

Collier, P. (1999). Calling the police to account: Coupling the operation of, and the accountability for policing - a field study of police force. paper presented at the Conference on Management Accounting Change - A European Perspective, Manchester: 14-17 April.

Copper, D. \& Hopper, T. (1990). Critical studies in Accounting. Accounting, Organizations and Society, 12, 407-414.

Covaleski, M., Dirsmith, M. \& Jablonsky, S., (1985). Traditional and emergent theories of budgeting: An empirical analysis. Journal of Accounting and Public Policy, 229-300.

Covaleski, M., Dirsmith, M. \& Michelman, J., (1993). An insitutionalist theory perspective on the DRG framework, case mix accounting systems and health care organizations. Accounting, Organizations and Society, 18 (1), 65-80.

Covaleski, M., Dirsmith, M. \& Samuel, S., (1996). Managerial accounting research: The contributions of organizational and sociological theories. Journal of Management Accounting Research, 8, 1-35.

Dawson, P. (1994). Organizational change: A Processual approach, London: Paul Chapman Publishing.

Drury, C. (1996). Management and Cost Accounting. London: Thompson.

Emmanuel, C. \& Otley, D. (1990). Accounting for management control. London: Chapman and Hall 
Ezzamel, M., Lilley, S. \& Willmott, H. (1997). Accounting for management and management accounting: reflection of recent changes in UK. Journal of Management Studies, 34 (3), 439-463.

Ezzamel, M., Willmott, H. \& Worthington, F. (1999). Accounting, organizational transformation and work organization. Paper presented at the Accounting, Organizations and Society Conference on "Accounting, Organizational Transformation and New Organizational Forms", USC, Los Angeles, 4-6 November.

Gietzmann, M. (1991). Implementation issues associated with the construction of an activity-based costing system in engineering components manufacturer. Management Accounting Research, 2, 189-199.

Hopper, T. (1999). Postcard from Japan: a management accounting view. Accounting, Auditing and Accountability Journal, 12 (1),5868.

Hopper, T. \& Armstrong, P. (1991). Cost accounting, controlling labour and the rise of the conglomerates. Accounting, Organizations and Society, 16 (5/6), 405-38.

Hopper, T. \& Powell, A. (1985). Making sense into the organizational and social aspects of management accounting: a review of its underlying assumptions. Journal of Management Studies, 22 (5), 429-65.

Hopwood, A. (1978). Towards an organizational perspective for the study of accounting and information systems. Accounting, Organizations and Society, 3 (1), 3-13.

Hopwood, A. (1983). On trying to study accounting in the contexts in which it operates. $A c$ counting, Organizations and Society, 8(2/3), 287-305.

Hopwood, A. (1987). The archaeology of accounting system. Accounting, Organizations and Society, 12: (3), 207-234.
Hopwood, A. (1990). Accounting and organizational change. Accounting, Auditing and Accountability Journal, 3 (1),7-17.

Innes, J. \& Mitchell, F. (1990a). Activity Based Costing: A review with case studies. London: The Chartered Institute of Management Accountants.

Innes, J. \& Mitchell, F. (1990b). The process of change in management accounting: some field studies evidence. Management Accounting Research, 1, 3-19.

Jacobs, K. (1995). Budgets: a medium of organizational transformation. Management Accounting Research, 1 3-19.

Johnson, T. \& Kaplan, R. (1987). Relevance lost: The rise and fall of Management Accounting. Boston, Mass.: Harvard Business School Press.

Kaplan, R. (1983). Measuring manufacturing performance: A new challenge for managerial accounting research. The Accounting Review, October, 686-705.

Kaplan, R. (1984). The evolution of management accounting. The Accounting Review, July, $390-418$.

Libby, T. \& Waterhouse, J. (1996). Predicting change in management accounting systems. Journal of Management Accounting Research, 8, 137-150.

Macintosh, N. (1985). The social software of Accounting and Information Systems. Chichester: John Wiley.

Macintosh, N. (1994). Management Accounting and control system. New York: John Wiley \& Sons.

Miller, P. (1994). Accounting as a social and institutional practice: An introduction, in A. Hopwood and A. Miller (eds.) Accounting as a social and institutional practice. Cambridge: Cambridge University Press, 1-39. 
Miller, P. \& O’Leary, T. (1987). Accounting and the construction of the governable person. Accounting, Organization and Society, 12, (3), 235-65.

Morgan, G. \& Willmott, H. (1993). The 'new' accounting research: On making accounting more visible. Accounting, Auditing and Accountability Journal, 6 (4), 3-36.

Mouck, T. (1992). The rhetoric of science and the rhetoric of revolt in the "story" of positive accounting theory. Accounting, Auditing and Accountability Journal, 5, (4), 35-56.

Otley, D. (1978). Budget use and managerial performance. Journal of Accounting Research, Spring, 122-49.

Otley, D. (1980). The contingency theory of management accounting: Achievement and prognosis. Accounting, Organizations and Society, 5 (4), 413-28.

Otley, D. (1984). Management accounting and organization theory: A review of their interrelationship, in R.W Scapens, D. T. Otley and R.J. Lister (Eds.) Management Accounting, Organizational Theory and Capital Budgeting, MacMillan/ESRC, 96-164.

Preston, A. (1995). Budgeting, creativity and culture, in Ashton, D., Hopper, T. \& Scapens, R. (Eds.) Issues in Management Accounting, Prentice-Hall, 273-297.

Puxty, A. (1993). The social and organisational context of Management Accounting, London: Academic Press.

Roslinder, R. (1995). Critical Management Accounting, in Ashton, D., Hopper, T. \& Scapens, R. (eds.) Issues in Management Accounting, Prentice-Hall, 65-86.

Scapens, R. (1990). Researching management accounting practice: The role of case study methods. British Accounting Review, 22, 259281.
Scapens, R. (1991). Management Accounting: A review of recent developments, $\left(2^{\text {nd }} \mathrm{Ed}\right)$. London: MacMillan.

Scapens, R. (1994). Never mind the gap: towards and institutional perspective of management accounting practices. Management Accounting Research, 22, 259-281.

Scapens, R. (1999). Broadening the scope of management accounting: from a microeconomic to a broader business perspective. Maandlad voor Accountancy en Bedrijfseconomie. December, 640-651.

Shields, M. (1997). Research in management accounting by North Americans in the 1990's. Journal of Management Accounting Research, 9, 3-61.

Schiff, M. \& Lewin, A. (1970). The impact of people on budgets. Accounting Review, April, 259-68.

Shiozawa, Y. (1999). Economics and accounting: a comparison between philosophical background of the two disciplines in view of the complexity theory. Accounting, Auditing and Accountability Journal, 12 (1), 19-38.

Spechler, M. (1990). Perspectives in Economic thought, New York: McGraw Hill.

Spicer, B. (1992). The Resurgence of cost and management accounting: a review of some recent developments in practice, theories and case research methods. Management Accounting Research, 3, 1-37.

Tinker, A.M., Merino, B.D. \& Neimark, M. D., (1982). The normative origin of positive theory. Accounting, Organization and Society, 7, 167-200.

Watts, R. \& Zimmerman, J. (1986). Positive Accounting Theory. Englewood Cliff, NJ : Prentice Hall. 
Willmott, H. (1983). Paradigms for accounting research: Critical reflections on Tomkins and Groves' Everyday accountant and researching his realities. Accounting, Organizations and Society, 8 (44), 389-405.

Whitley, R. (1988). The possibility and utility of positive accounting theory. Accounting, Organizations and Society, 13 (6), 631-645.
Young, S.M. (1999). Field research methods in management accounting. Accounting Horizons, 13 (1), 76-84.

Vaivio, J. (1999). Exploring a 'non-financial' management accounting change. Management Accounting Research, 10, 409-437. 